\title{
Independensi Penentuan Jumlah Nilai Agunan dalam Perjanjian Kredit yang Dilakukan oleh Appraisal Bank
}

\author{
Elysabet Sry Devi Bruni Simatupang, Sunarmi, Mahmul Siregar, Utary \\ Maharany Barus
}

CoA.Email : elysabet.simatupang@gmail.com

\begin{abstract}
A bank always requires collateral to its customers in providing credit facility as a form of a guarantee or responsibility for their contract with the bank. A bank also employs an Appraisal Bank or Public Appraisal Service Office (KJPP). KJPP is expected to prevent wrong collateral valuation and value engineering. Therefore, the research problems are how the independence of an Appraisal Bank is, in performing collateral valuation in a credit contract, how the binding force of the valuation results gained by an Appraisal Bank to the collateral in a credit contract, and how the liability of the Appraisal Bank for the valuation performed by an Appraisal Bank to the collateral in a credit contract. This is a normative juridical and descriptive research. This research employs statutory method using primary, secondary, and tertiary legal materials. The data are collected from library study and field observation. They are analyzed by reducing data, presenting data, and drawing conclusions/making verification to obtain descriptive data. The results of the research conclude that the independence an. appraisal is assessed when he performs valuation without intervention from anyone. In legal view, an appraisal is considered valid and affecting the collateral object; the results of his valuation becomes his responsibility. The responsibility of an appraisal for his valuation results can be seen from the conformity of his report and the prevailing regulations. It is suggested that one be required and obliged to have specific skills, integrity, honesty and objectivity to become an appraisal. An appraisal also has to be guided by ethical codes and prevailing laws and regulations.
\end{abstract}

Key Words : independence, credit, appraisal bank 


\section{A. PENDAHUluan}

Perbankan merupakan salah
satu lembaga keuangan yang
mempunyai pengaruh dalam
perkembangan perekonomian suatu
Negara. Pemberian kredit yang aman
harus disertai dengan adanya jaminan
karena jaminan merupakan hal yang
penting dalam melaksanakan
perjanjian kredit,juga melindungi
kepentingan para pihak khususnya
kreditur.

Bank dalam pemberian kredit kepada nasabah akan selalu meminta agunan sebagai bentuk dari suatu jaminan atau pertanggungjawabannya untuk mengikatkan dirinya kepada pihak perbankan. Akan tetapi sering sekali di dalam proses tersebut dalam hal memberikan penilaian terhadap nilai agunan nasabah, pihak bank menggunakan Apraissal Bank atau Kantor Jasa Penilai Publik (KJPP) dalam hal membantu menilai jumlah agunan yang dimiliki oleh nasabah.

Dengan dipakainya jasa penilai publik tersebut diharapkan penilaian agunan tidak salah dan tidak terjadi rekayasa nilai agunan (over value). Usaha jasa penilai (appraisal service business) merupakan usaha jasa profesional untuk memberikan penilaian yang obyektif dan independen terhadap aset atau property (Jopie 2004).

Oleh karena itu perlu untuk melakukan penelitian mengenai Independensi seorang Appraisal Bank dalam melakukan penilaian terhadap nilai agunan, karena tidak menutup kemungkinan terjadinya over value (nilai agunan yang direkayasa lebih besar dari nilainya) atau lower value (nilai agunan yang direkayasa lebih kecil nilainya). Sehingga dalam dunia perbankan di Indonesia dapat diminimalisasikan tingkat resiko terhadap hasil penilaian yang dilakukan oleh seorang appraisal dalam hal ini sebagai pemberi jasa yang dinilai profesional karena telah mendapatkan pendidikan dan pelatihan-pelatihan yang banyak untuk dapat memberikan hasil penilaian yang baik terhadap apa yang dilakukannya.

\section{B. IDENTIFIKASI MASALAH}

Berdasarkan latar belakang
tersebut, maka yang menjadi
permasalahan penelitian ini ada tiga,
yaitu: Pertama, Bagaimana
independensi Appraisal Bank dalam
memberikan penilaian terhadap
agunan dalam suatu perjanjian
kredit?. Kedua, Bagaimanakah


kekuatan mengikat terhadap hasil penilaian yang dilakukan oleh Appraisal Bank terhadap agunan dalam perjanjian kredit?. Dan terakhir, bagaimana tanggung jawab Appraisal Bank terhadap hasil penilaian yang dilakukannya atas agunan dalam suatu perjanjian kredit? Metode penelitian yang digunakan dalam penulisan ini dilakukan dengan studi kasus. Tipe penelitiannya adalah Research Legal dengan pendekatan kualitatif. Datadata dalam penelitian ini dikumpulkan melalui wawancara mendalam, observasi dan studi literasi tehadap bahan-bahan yang berhubungan dengan penelitian. Dalam penelitian ini tidak akan dibedakan data primer dan skunder, melainkan semua data diposisikan dalam posisi yang sama sehingga diharapkan dapat menggambarkan kasus yang diteliti secara utuh.

\section{Pembahasan}

\section{Kerangka teori}

a. Teori pertanggungjawaban

Ada dua istilah yang menunjuk pada pertanggungjawaban dalam kamus hukum, yaitu liability dan responsibility. Liability merupakan istilah hukum yang luas yang menunjuk hampir semua karakter risiko atau tanggung jawab, yang pasti, yang bergantung atau yang mungkin meliputi semua karakter hak dan kewajiban secara aktual atau potensial seperti kerugian, ancaman, kejahatan, biaya atau kondisi yang menciptakan tugas untuk melaksanakan undang-undang. Responsibility berarti hal yang dapat dipertanggungjawabkan atas suatu kewajiban, dan termasuk putusan, ketrampilan, kemampuan dan kecakapan meliputi juga kewajiban bertanggung jawab atas undangundang yang dilaksanakan. Dalam pengertian dan penggunaan praktis, istilah liability menunjuk pada pertanggungjawaban hukum, yaitu tanggung gugat akibat kesalahan yang dilakukan oleh subyek hukum, sedangkan istilah responsibility menunjuk pada pertanggungjawaban politik. (Ridwan, 2006)

b. Teori Kepastian Hukum

Tentang teori kepastian hukum, Soerjono Soekanto mengemukakan “wujud kepastian hukum adalah peraturan-peraturan dari pemerintah pusat yang berlaku umum diseluruh wilayah negara. Kemungkinan lain adalah peraturan tersebut berlaku umum, tetapi bagi golongan tertentu, selain itu dapat pula peraturan 
setempat, yaitu peraturan yang dibuat oleh penguasa setempat yang hanya berlaku di daerahnya saja,misalnya peraturan kotapraja". (Soekanto, 1974 :56)

Teori kepastian hukum menandai landasan bagi para pihak dalam perjanjian kredit terhadap nilai dari benda yang menjadi objek penilaian Appraisal nasional. Menurut teori ini, hukum mempunyai tugas suci dan luhur ialah keadilan dengan memberikan kepada tiap-tiap orang apa yang berhak iaterima serta memerlukan peraturan tersendiri bagi tiap-tiap kasus.

Untuk terlaksananya hal tersebut, maka menurut teori ini hukum harus membuat apa yang dinamakan "Algemen Regels" (peraturan/ketentuan umum). Dimana peraturan/ketentuan umum ini diperlukan masyarakatdemi kepastian hukum. Jika dikaitkan dengan penelitian ini, teori kepastian hukum menandai landasan bagi debitur untuk mendapatkan kepastian mengenai nilai dari benda yang menjadi objek bagi seorang Appraisal Bank atau Jasa Penilai Publik.
2. Aspek Hukum Agunan dalam Perjanjian Kredit

a. Perjanjian Kredit Dalam Perspektif Hukum Indonesia

Perjanjian kredit merupakan salah satu jenis perjanjian yang segala ketentuan umumnya didasarkan pada ajaran umum hukum perikatan yang terdapat dalam KUHPerdata. Ketentuan umum dalam KUH Perdata tersebut menjadi dasar atau asas umum yang konkrit dalam membuat semua perjanjian apapun. (Sutamo, 2004: 68) Setiap kredit yang disetujui dan disepakati antara pihak kreditur dan debitur maka wajib dituangkan dalam perjanjian kredit (akad kredit) secara tertulis.

Berkenaan dengan praktik perbankan bentuk dan format dari perjanjian kredit diserahkan sepenuhnya kepada bank yang bersangkutan. Namun ada hal-hal yang tetap harus dipedomani, yaitu bahwa perjanjian tersebut rumusannya tidak boleh kabur atau tidak jelas, selain itu juga perjanjian tersebut sekurang-kurangnya harus memperhatikan keabsahan dan persyaratan secara hukum, sekaligus juga harus memuat secara jelas mengenai jumlah besarnya kredit, jangka waktu, tata cara pembayaran 
kembali kredit serta persyaratan lainnya yang lazim dalam perjanjian kredit.(Djumhana, 2003: 238)

Perjanjian kredit yang sudah disiapkan oleh bank dalam bentuk standar (standard form). Perjanjian kredit yang dibuat dalam bentuk akta notariil atau akta otentik biasanya untuk pemberian kredit dalam jumlah yang besar dengan jangka waktu menengah atau panjang seperti kredit investasi, kredit modal kerja, kredit sindikasi (kredit yang diberikan lebih dari satu kreditur atau lebih dari satu bank). (Kusumaningrum, 2008)

b. Pengelolaan Resiko dalam Perjanjian Kredit

Kredit seperti halnya produk jasa perbankan lainnya mempunyai risiko yang sesuai dengan penggunaan dana tersebut. Untuk penempatan dana yang dipinjamkan. Risiko dalam kredit itu sendiri dapat dilihat dalam dua sisi, yaitu dari sisi bank sebagai kreditur dan nasabah sebagai debitur disisi lainnya. Masingmasing pihak tersebut mempunyai risiko berbeda dalam pelaksanaan perjanjian kredit bank tersebut.

c. Kedudukan Agunan dalam Perjanjian Kredit

Pada prakteknya, bank harus melakukan analisis pemberian kredit agar terhindar dari potensi menjadi kredit macet. Kredit bank mengandung resiko, sehingga dalam pelaksanaanya bank harus memperhatikan asas-asas perkreditan yang sehat. (Murti, 2010: 56)

d. Peran Appraisal Bank dalam Perjanjian Kredit

Usaha Jasa Penilai (appraisal service business) merupakan usaha jasa profesional untuk memberikan penilaian yang obyektif dan independen terhadap asset atau properti. Dimana lembaga ini berpredikat sebagai lembaga kepercayaan yang dibutuhkan untuk kepentingan pihak-pihak yang mengadakan transaksi perdagangan. (Kasmir, 2008: 68)

e. Ruang Lingkup Kegiatan Appraisal Bank dalam Perjanjian Kredit

Perusahaan Penilai (Appraisal Company) atau Usaha Jasa Penilai di Indonesia merupakan bentuk usaha yang relatif masih baru, sehingga usaha ini belum diatur secara khusus dalam KUHPerdata maupun dalam KUHD. Di samping itu, bentuk usaha ini belum begitu banyak dikenal di masyarakat umum atau belum memasyarakat, kecuali masyarakat pengusaha, inipun terbatas pada pengusaha golongan tertentu saja. 
Sehingga banyak kalangan belum mengerti apa yang dimaksud dengan Usaha Jasa Penilai.

f. Peran Appraisal Bank dalam Perjanjian Kredit

Di Indonesia, peraturan pertama yang mengatur tentang jasa penilai adalah Surat Keputusan Menteri Perdagangan No. 161/KP/VI/1977 tentang Ketentuan Perjanjian Usaha Penilaian di Indonesia. Kemudian menyusul Keputusan Menteri Keuangan RI No. 57/KMK.017/1996 tentang Jasa Penilai, Keputusan Presiden No. 35 tahun 1992 yang diantaranya berisi pembentukan Direktorat Jenderal Lembaga Keuangan yang salah satu bagiannya adalah Direktorat Pembinaan Akuntan dan Jasa Penilai, terakhir pengaturan tentang Perusahaan Jasa Penilaian di atur dalam Peraturan Menteri Keuangan Republik Indonesia Nomor 125/Pmk.01/2008 Tentang Jasa Penilai Publik.

g. Independensi Appraisal Bank dalam Memberi Penilaian Terhadap Agunan dalam Perjanjian Kredit

$$
\text { Kedudukan Independen }
$$

Profesi ini akan terkait dengan objektifitas hasil penilaian. Sikap
Independen oleh Penilai Bank atas agunan dianggap mempunyai objektifitas yang lebih baik dibandingkan apabila agunan tersebut dinilai sendiri oleh penaksir internal yang dimiliki oleh pihak bank. Tidak ada aturan yang mengharuskan pemakaian Penilai Publik untuk menilai agunan sebagai persyaratan kredit.Sehingga bank menunjuk Penilai hanya sebatas untuk lebih berhati-hati dalam menjalankan kegiatannya sehingga resiko kerugian dapat diminimalkan.

2. Kekuatan Mengikat Terhadap Hasil Penilaian Appraisal Bank Terhadap Agunan Dalam Perjanjian Kredit

a. Dasar Penunjukan Appraisal Bank dalam Memberikan Penilaian Agunan

$$
\text { Appraisal menjalankan }
$$
tugasnya sesuai kompetensinya sebagaimana amanat peraturan perundang-undangan sebagai penyedia Jasa penilaian. Tidak hanya menjalankan tugasnya sesuai Peraturan Menteri Keuangan, pedoman lain Appraisal menjalankan tugasnya dituliskan pada Peraturan Menteri Keuangan Nomor 101/PMK.01/2014 tentang Penilai Publik, Standar Penilaian Indonesia 
(SPI) dan Kode Etik Penilai Indonesia (KEPI), Gabungan Asosiasi Penilai Indonesia (GAPI), Masyarakat Profesi Penilai Indonesia (MAPPI) dan kontrak Perjanjian dengan Pihak Bank.

b. Hubungan Hukum Antara Appraisal Bank dengan PihakPihak dalam Perjanjian Kredit Hubungan hukum antara jasa penilai publik dalam pihak bank dalam menilai agunan tanah dan bangunan untuk kepentingan penilaian jaminan kredit menunjukkan alur perjanjian dimana perusahaan jasa penilai berhubungan langsung dengan pihak bank, di sini yang terkait perjanjian hanya KJPP dengan pihak bank, sedangkan pemilik aset tidak berhubungan langsung dengan perusahaan penilai. Permintaan penilai oleh pihak bank merupakan salah satu syarat yang harus dipenuhi oleh debitur untuk menentukan berapa besar pinjaman yang dapat diberikan oleh bank kepada calon debitur.( Wawancara 2019)

c. Proses dan Mekanisme Penilaian Agunan dalam Perjanjian Kredit

Proses penilaian adalah merupakan proses ilmiah yang terdiri dari beberapa tahapan yang berupa identifikasi masalah, perencanaan penilaian, pengumpulan data dan analisa yang kemudian dilakukan penilaian dengan tiga cara pendekatan yaitu pendekatan biaya, pendekatan data pasar dan pendekatan pendapatan. Dari hasil penilaian berdasarkan atas ketiga pendekatan tersebut kemudian dilakukan pemaduan indikasi nilai sehingga akan dihasilkan taksiran akhir atas nilai aktiva bersangkutan.

d. Kekuatan Mengikat Hasil Penilaian Agunan yang Dilakukan oleh Appraisal Bank

Prinsip-prinsip tersebut digunakan oleh seorang appraisal bank sebelum melakukan analisa terhadap agunan yang akan dinilai, dan setelah seorang appraisal selesai melakukan penilaian berdasarkan metode-metode yang telah ditentukan oleh bank, maka terhadap hasil penilaian tersebut akan langsung mengikat kepada objek agunan yang dinilai, berapapun hasil dari penilaian itu sudah menjadi tanggungjawab dari seorang appraisal sendiri. Seorang appraisal bank melakukan penilaian didasarkan kepada Job Desk-nya sebagai seorang appraisal, salah satunya dalam hal menganalisa nilai agunan. (Wawancara, 2019) 
Penilaian yang dilakukan seorang appraisal bank dapat dirubah apabila hasil penilaian tersebut tidak sesuai dengan nilai yang seharusnya, dan hasil keputusan akhir dari penilaian tersebut akan ditandatangani oleh pimpinan cabang dan juga ditandatangani si kreditur, oleh karena itu si kreditur dianggap telah mengetahui dan menyetujui hasil dari penilaian yang telah diputuskan oleh bank. (Wawancara, 2019)

3. Tanggung Jawab Appraisal Bank Terhadap Hasil Penilaian Agunan a. Tanggung Jawab Profesi Penilaian Dalam Perspektif Etika Profesi dan Hukum

Berbicara mengenai tanggung jawab sebagai seorang penilai, menurut Kode Etik Penilai Indonesia (KEPI) seorang penilai memiliki 4 (empat) bentuk tanggung jawab yang terdiri dari :

1. Tanggung Jawab terhadap integritas Pribadi Penilai

2. Tanggung Jawab terhadap Pemberi Tugas

3. Tanggung Jawab terhadap sesama Penilai dan Usaha Jasa Penilai

4. Tanggung Jawab terhadap masyarakat.
b. Bentuk-Bentuk Penyimpangan dalam Penilaian Agunan oleh Appraisal Bank

$$
\text { Dalam beberapa dekade }
$$
terdapat berbagai perbuatan malpraktek yang dilakukan oleh penilai atau Perusahaan Jasa Penilai di Indonesia, kasus-kasus tersebut antara lain:

a) Kasus Penilaian Tanah Kosong

b) Kasus Over Value (Saliman, 2004)

c) Kasus Persaingan AntarPerusahaan Penilai di Indonesia

Kasus-kasus di atas telah mencerminkan adanya perbuatan malpraktek yang dilakukan Penilai, dan perbuatan melawan hukum oleh pemilik aset berupa penjarahan barang-barang perusahaannya sendiri, sehingga membuat penilaian berbeda. Mungkin saja banyak kasuskasus lain yang tidak diketahui masyarakat. Perbuatan-perbuatan malpraktek yang dilakukan penilai merupakan perbuatan yang dapat dimintai pertanggungjawaban hukumnya, namun perlu dibuktikan.

c. Tanggung Jawab Profesi Penilai atas Hasil Penilaian Terhadap Agunan dalam Perjanjian Kredit 
Berdasarkan Pasal 45

Permenkeu No. 101/PMK.01/2014 tentang Jasa Penilai Publik maka apabila bank merasa mengalami kerugian dalam pemberian kredit dikarenakan penilai tidak melaksanakan penilaian dengan baik atau sengaja melakukan malpraktik maka bank dapat meminta pertanggungjawaban dari penilai.

Adapun pertanggungjawaban yang dapat dikenakan terhadap penilai yakni pertanggungjawaban perdata bertujuan untuk memperoleh kompensasi atas kerugian yang diderita, di samping untuk mencegah terjadinya hal-hal yang tidak diinginkan. Itulah sebabnya baik wanprestasi maupun perbuatan melawan hukum merupakan dasar untuk menuntut tanggung jawab perusahaan penilai. Tanggung jawab karena kesalahan merupakan bentuk klasik pertanggungjawaban perdata berdasarkan tiga prinsip yang diatur dalam Pasal 1365, Pasal 1366 dan Pasal 1367 KUH Perdata.

\section{Sama}

pertanggungjawaban pertanggungjawaban pidana dapat dikenakan, akan tetapi hanya terhadap personil (Penilai) yang melaksanakan kegiatan.
Pertanggungjawaban pidana selalu berhubungan erat dengan unsur kesalahan. Untuk menentukan adanya kesalahan seseorang harus dipenuhi beberapa unsur: (Saleh, 1983)

a) Adanya kemampuan bertanggung jawab pada si pembuat;

b) Hubungan batin antara si pembuat dan perbuatannya yang berupa kesengajaan (dolus) atau kealpaan (culpa);

c) Tidak adanya alasan penghapus kesalahan atau tidak adanya alasan pemaaf.

d. Perlindungan Hukum Terhadap Pihak-Pihak dalam Perjanjian Kredit Terhadap Kesalahan dalam Penilaian Agunan oleh Appraisal Bank

Berdasarkan pasal 45 Peraturan Menteri Keuangan tentang Jasa Penilai Publik jo angka 7.1.2 KEPI maka apabila bank merasa mengalami kerugian dalam pemberian kredit dikarenakan penilai tidak melaksanakan penilaian dengan baik atau sengaja melakukan malpraktik maka bank dapat meminta pertanggungjawaban dari penilai. Hubungan hukum antara Penilai Publik dengan Bank dalam menilai agunan dari calon debitor sesuai dengan peraturan yang berlaku harus 
dibuat dan dituangkan dalam suatu perjanjian tertulis yang didalamnya mengakomodir diwajibkannya Penilai Publik untuk mematuhi KEPI dan SPI dalam menjalankan kegiatan penilaian agar hasil penilaian terhadap benda agunan dapat menghasilkan laporan penilaian yang akurat dan sebaik mungkin sesuai fakta.

Dengan demikian apabila bank merasa penilaian yang dilakukan oleh Penilai Publik tidak tepat yang karena Penilai Publik tidak memenuhi perjanjian yang telah dibuat khususnya tidak melaksanakan KEPI dan SPI sebagai pedoman dalam penilaian sehingga nilai taksiran atas agunan yang disampaikan dalam laporan penilaian dianggap keliru yang berakibat terjadinya kesulitankesulitan atas kredit yang diberikan kepada debitor termasuk terjadinya kredit macet maka Penilai Publik dapat digugat menggunakan dasar wanprestasi.

\section{KESIMPULAN}

Berdasarkan pembahasan di atas, maka dapat disimpulkan beberapa hal penting, yakni sebagai berikut :
1. Penilaian aset secara tepat sangat diperlukan dalam dunia perbankan. Kesalahan atau ketidakakuratan dalam menilai suatu properti akan mengakibatkan beberapa masalah dalam rangka likuidasi/lelang maupun dalam penghitungan penyisihan aktiva produktif. Untuk itu independensi dan profesionalisme seorang Appraisal dalam melakukan penilaian sangat diperlukan. Ukuran independensi seorangappraisal adalah ketika dia melakukan penilaian tidak ada intervensi dari pihak manapun, sebagai seorang pemberi jasa yang professional dia dituntut untuk jujur, teliti sehingga apa yang menjadi hasil dari laporan penilaiannya dianggap benar dan valid yang wajib berpedoman kepada Standar Penilaian Indonesia (SPI) dan Kode Etik Penilai Indonesia (KEPI) yang disusun oleh komite yang dibentuk oleh Masyarakat Profesi Penilai Indonesia (MAPPI) dan Gabungan Perusahaan Penilai Indonesia 
(GAPPI) Standar Penilaian Indonesia (SPI).

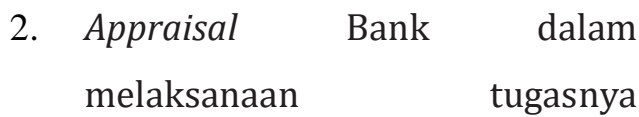
menggunakan beberapa tahapan untuk menentukan arah kerja appraisal agar mendapatkan laporan yang sesuai dengan kebutuhann pelanggan. Proses penilaian tersebut harus dilakukan sesuai dengan SPI sebagai pedoman kerja Appraisal Bank yaitu pada Pasal 4 ayat (1) Peraturan Menteri Keuangan Nomor 101/PMK 01/2014 tentang Penilai Publik. Secara hukum hasil penilaian dari seorang appraisal dianggap sah dan berpengaruh terhadap kepada objek agunan yang dinilai, berapapun hasil dari penilaian itu sudah menjadi tanggungjawab dari seorang appraisal sendirikarena telah disetujui dan ditandatangani oleh si debitur, namun hasil laporan penilaian yang dilakukan seorang appraisal bank dapat dirubah apabila hasil penilaian tersebut tidak sesuai dengan nilai yang seharusnya, dan hasil keputusan akhir dari penilaian tersebut akan ditandatangani oleh pimpinan cabang sebagai perwakilan dari pihak bank atau debitur dan juga ditandatangani si kreditur, oleh karena itu si kreditur dianggap telah mengetahui dan menyetujui hasil dari penilaian yang telah diputuskan oleh bank.

3. Appraisal sebagai jasa penilai yang dianggap professional sudah memiliki beberapa peraturan yang menjamin adanya suatu kepastian hukum bagi para pihak yang ada di dalam suatu perjanjian kredit yaitu Surat Keputusan Menteri Perdagangan No. 161/KP/VI/1977 tanggal 17 Juni 1977 tentang ketentuan Perizinan Usaha Penilai, Keputusan Menteri keuangan No. 57/KMK.017/1996 tentang Jasa Penilai, Peraturan Menteri Keuangan Republik Indonesia No. 101/PMK.01/2014 tentang Penilai Publik. Standar Penilaian Indonesia (SPI) dan Kode Etik Penilaian Indonesia (KEPI). Tanggungjawab appraisal terhadap hasil penilaiannya dapat dilihat dari kesesuaian hasil laporan dengan aturanaturan yang berlaku tersebut. Jika seorang Appraisal Bankmelakukan kesalahan 


dengan memberikan hasil
penilaian yang over value atau
lower value maka akan dikenai
tanggungjawab berupa teguran
tertulis, penurunan jabatan,
bahkan dilakukan Pemutusan
Hubungan Kerja (PHK), karena
hasil penilaian tersebut akan
berpengaruh terhadap jumlah
pinjaman yang diberikan didalam
perjanjian kredit.

\section{DAFTAR PUSTAKA}

Amiruddin, Zainal dan Asikin. Metode Penelitian Hukum. Bandung: PT. Citra Aditya Bakti, 2006.

Djumhana, Muhammad. Hukum Perbankan di Indonesia. Bandung : Citra Aditya Bakti, 2003.

H.R, Ridwan. Hukum Administrasi Negara. Jakarta : Raja Grafindo Persada, 2006.

Jusuf, Jopie. Kiat Jitu Memperoleh Kredit Bank. Jakarta : PT Elex Media Komputindo Kelompok Gramedia, 2004.

Kamello, Tan. Perkembangan Lembaga Jaminan Fidusia : Suatu Tinjauan Putusan Pengadilan dan Perjanjian di Sumatera Utara. Medan : Disertasi PPs USU, 2002.

Kasmir. Dasar-Dasar Perbankan. Jakarta: Raja Grafindo Persada, 2005. Kusumaningrum, Dyah. Pelaksanaan Perjanjian Kredit yang Diikat dengan Jaminan Fidusia di PT Bank Eksekutif Internasional, Tbk Cabang Semarang,
(Tesis, Program Pasca Sarjana. Universitas Diponegoro, Semarang, 2008.

Murti, Indah Antari. "Perjanjian Kredit dengan Jaminan Fidusia Atas Kendaraan Bermotor Yang Dijual Pada Pihak Ketiga Pada PT. Bank Danamon (Persero) Tbk Unit DSP Pracimantoro Wonogiri", Tesis, Program Studi Magister Kenotariatan. Semarang: Universitas Diponegoro, 2010.

Saleh, Roeslan. Perbuatan Pidana dan Pertanggungjawaban Pidana; Dua Pengertian Dasar dalam Hukum Pidana. Jakarta : Aksaran Baru, 1983.

Saliman, Abdul R. Esensi Hukum Bisnis Indonesia, Teori dan Contoh Kasus. Jakarta: Prenada, 2004.

Soekanto, Soerjono. Beberapa Permasalahan Hukum Dalam Kerangka Pembangunan Indonesia. Jakarta : UI Pres, 1974.

Sutarno. Aspek-Aspek Hukum Perkreditan Pada Bank. Bandung : Alfabeta, 2004. 